\title{
Pengembangan Perangkat Pembelajaran Biologi Sma Berbasis Potensi Lokal, Literasi Lingkungan Dan Sikap Konservasi
}

\author{
Adi Pasah Kahar ${ }^{1 *}$, Raudhatul Fadhilah ${ }^{2}$ \\ ${ }^{1,2}$ Pendidikan Biologi, FKIP, Universitas Muhammadyah Pontianak, Pontianak, Indonesia
}

\begin{abstract}
This research aims to develop high school biology teaching kits based on local potential, environmental literacy, and conservation in Kubu Raya Regency. This research used development method refers to the model Thiagarajan (2007). The definition stage carried out by identifying potential local Kubu Raya regency and analyze the needs of high school biology teaching kits. The design stage done to design a teaching kits format. The development stage of teaching kits already validated by 3 teachers of biology in Kubu Raya high school. Limited trial teaching kits done in class X SMAN 2 Kubu Raya. The average score validation results indicate that teaching kits worthy to use. The practicality of the taching kits test response on average $82 \%$ with criteria very well. The teaching kits is very effective learning based on student learning score value of $86.67 \%$. Biology teaching kits have very valid criteria, practical, and effective way so that it can be implemented widely in biology learning at high school.
\end{abstract}

Keywords: conservation, environmental literacy, local potency, teaching kits

\begin{abstract}
ABSTRAK: Penelitian ini bertujuan untuk mengembangkan perangkat pembelajaran biologi SMA berbasis potensi lokal, literasi lingkungan, dan sikap konservasi. Penelitian ini merupakan penelitian pengembangan yang mengacu pada model Thiagarajan (2007). Tahap pendefinisian dilakukan dengan mengidentifikasi potensi lokal Kabupaten Kubu Raya dan menganalisa kebutuhan perangkat pembelajaran biologi di SMA Kabupaten Kubu Raya. Tahap perancangan dilakukan untuk merancang format perangkat pembelajaran. Tahap pengembangan menghasilkan perangkat pembelajaran yang sudah divalidasi 3 orang guru biologi. Uji coba terbatas terhadap perangkat (RPP, bahan ajar, dan LKS) dilakukan di kelas X SMAN 2 Kubu Raya. Rata-rata skor hasil validasi menunjukkan bahwa semua perangkat pembelajaran layak digunakan. Kepraktisan perangkat (RPP, Bahan Ajar, dan LKS) pada uji coba mendapatkan respon rata-rata $82 \%$ dengan kriteria sangat baik. Perangkat pembelajaran sangat efektif berdasarkan nilai ketuntasan belajar siswa sebesar $86.67 \%$. Perangkat pembelajaran biologi memiliki kriteria sangat valid, praktis, dan efektif sehingga dapat diimplementasikan secara luas dalam pembelajaran.
\end{abstract}

Kata Kunci: konservasi, literasi lingkungan, potensi lokal, perangkat pembelajaran

*Penulis Korespondensi:

Alamat surel: adipasahkahar@unmuhpnk.ac.id 


\section{PENDAHULUAN}

Kabupaten Kubu Raya merupakan wilayah pemekaran dari Kabupaten Pontianak Propinsi Kalimantan Barat. Dengan garis pantai sepanjang $194 \mathrm{Km}$, pulau-pulau kecil sebanyak 31 buah, dan luas daratan $6.985 \mathrm{~km} 2$ yang terdiri dari rawa serta Daerah Aliran Sungai (DAS) Kapuas menjadikan wilayah Kabupaten Kubu Raya sebagai daerah yang mempunyai potensi lokal yang sangat beragam di Kalimantan Barat (Almutahar, 2013). Pada tahun 2015, Kabupaten Kubu Raya terdiri dari 9 wilayah Kecamatan, yaitu: Batu Ampar, Terentang, Kubu, Teluk Pakedai, Sungai Kakap, Rasau Jaya, Sungai Raya, Sungai Ambawang, dan Kuala Mandor B. Hal ini menyebabkan potensi lokal Kabupaten Kubu Raya yang sangat beragam. Potensi lokal Kabupaten Kubu Raya perlu dikembangkan dengan lebih baik lagi. Keunggulan yang dimiliki harus dimaksimalkan. Dengan adanya keberagaman potensi lokal ini, pengembangan potensi dan keunggulan lokal perlu mendapat perhatian secara khusus oleh pemerintah daerah Kabupaten Kubu Raya, sehingga putra daerah tidak merasa asing dengan daerahnya sendiri dan paham tentang potensi lokal yang ada di daerahnya sendiri serta dapat mengembangkan potensi lokal daerah (Yunisfu 2013).

Potensi lokal pada intinya merupakan sumber daya yang ada dalam suatu wilayah tertentu. Potensi lokal berkembang dari tradisi kearifan yang dimiliki oleh suatu masyarakat yang bersahaja sebagai bagian dari kebudayaannya. Mengacu kepada pendapat Victorino (2004), ciri umum dari potensi lokal adalah: a) ada pada lingkungan suatu masyarakat, b) masyarakat merasa memiliki, c) bersatu dengan alam, d) memiliki sifat universal, e) bersifat praktis, f) mudah dipahami dengan menggunakan common sense, g) merupakan warisan turun temurun. Potensi lokal mempunyai makna sebagai sumber/kekuatan yang dimiliki oleh masing-masing daerah untuk dapat dimanfaatkan dalam kegiatan-kegiatan tertentu, salah satunya bidang pendidikan. Potensi lokal tidak terlepas dari konsep masukan lingkungan sebagai pendukung untuk berlangsungnya proses pembelajaran. Dengan memanfaatkan potensi yang ada di masyarakat, diharapkan masyarakat tidak merasa asing, sehingga motivasi untuk mengembangkan berbagai program pembelajaran terus meningkat (Ihat 2006).

Potensi lokal dapat dihubungkan dengan realitas lokal dan lingkungan lokal. Realitas lokal adalah semua kondisi dan kehidupan nyata serta fenomena yang ada di lingkungan sekitar (tempat hidup) siswa yang disusun secara sistematis yang di dalamnya termasuk lingkungan fisik, sosial, pemahaman, keyakinan, dan wawasan lokal siswa (Achyani, 2010). Lingkungan lokal dapat diartikan sebagai fenomena, peristiwa, permasalahan atau kejadian tentang pencemaran lingkungan dan keanekaragaman hayati di sekitar siswa (Marlina, 2013). Hal ini tentu saja dapat dikaitkan dengan proses pembelajaran di bidang sains sehingga mampu mendorong siswa membangun konsep mereka sendiri, bersifat kontekstual, melibatkan aspek-aspek kehidupan sehari-hari siswa, dan memanfaatkan alam sekitar, lingkungan dan potensi lokal di mana siswa berada, sehingga dapat meningkatkan kemampuan literasi sains siswa (Putri, 2014).

Pembelajaran di bidang sains berkembang pesat disertai dengan perkembangan teknologi sebagai 
wujud aplikasi sains. Sains dan teknologi berkembang disesuaikan dengan kompleksitas kebutuhan masyarakat global (Santoso 2010). Selain menyumbangkan manfaat positif bagi masyarakat, perkembangan sains dan teknologi juga mengakibatkan terbentuknya berbagai aktivitas negatif seperti eksplorasi sumber tambang, pemanfaatan hutan secara bebas, perburuan hewan lindung dan sebagainya. Oleh karena itu, diperlukan bekal literasi lingkungan dan sikap konservasi siswa yang kokoh dalam mengikuti arus perkembangan sains dan teknologi tetapi masih peduli terhadap kelestarian lingkungan. Ilmu Sains adalah "pengetahuan yang diperoleh melalui pembelajaran dan pembuktian" atau "pengetahuan yang melingkupi suatu kebenaran umum dari hukum-hukum alam yang terjadi misalnya didapatkan dan dibuktikan melalui metode ilmiah". Sains dalam hal ini merujuk kepada sebuah sistem untuk mendapatkan pengetahuan yang dengan menggunakan pengamatan dan eksperimen untuk menggambarkan dan menjelaskan fenomenafenomena yang terjadi di alam (Khusniati 2014).

Pada masa kini kondisi lingkungan masih terabaikan dari perhatian dunia akademik termasuk sekolah. Sekolah belum dapat mentransmikisan pengetahuan bermuatan lingkungan sehingga siswa belum memiliki kecerdasan ekologis atau literasi ekologi. Di sisi lain, pendidik juga kurang memanfaatkan lingkungan sebagai sumber dan media pembelajaran (Valentine 2015). Permasalahan tentang lingkungan kebanyakan masih hanya sebatas diberikan pada ranah kognitif, sehingga tidak mengherankan jika yang terjadi adalah pengetahuan tentang lingkungan yang dihafalkan, berkutat sebatas definisi dari buku pegangan siswa, sampai pada lembar evaluasi siswa sangat jarang yang mengukur dari aspek afektif dan psikomotor yang terkait dengan permasalahan lingkungan (Surata 2010).

Uraian tersebut menjadi salah satu permasalahan dalam pembelajaran biologi (Mumpuni 2013). Relevansi potensi lokal dengan dunia nyata mendorong terbentuknya aplikasi praktis pada pembelajaran kontekstual biologi. Oleh karena itu, pembelajaran biologi harus memuat pengetahuan dan sikap konservasi tentang potensi lokal setempat sehingga dapat memotivasi siswa untuk belajar dan mengembangkan keterampilan sesuai potensi lokal. Biologi berperan dalam mengembangkan potensi sumber daya lokal dan membelajarkan tentang bagaimana pemanfaatan dan pelestariannya.

\section{METODE PENELITIAN}

Bentuk penelitian yang dilakukan dalam penelitian ini adalah penelitian pengembangan (research \& development). Model pengembangan yang digunakan dalam penelitian ini adalah model pengembangan 4-D yang disarankan Thiagarajan. Prosedur pengembangan menurut Thiagarajan meliputi pendefinisian (define), perancangan (design), pengembangan (develop) dan penyebaran (disseminate). 


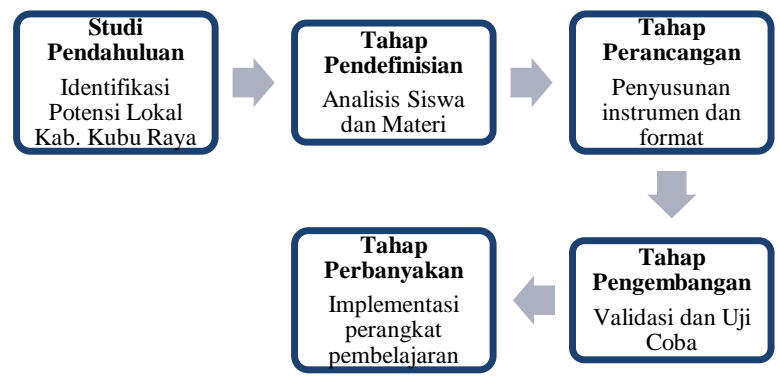

Gambar 1. Metode Penelitian

Perangkat pembelajaran yang dikembangkan meliputi Rencana Pelaksanaan Pembelajaran (RPP), Bahan Ajar, dan Lembar Kegiatan Siswa (LKS). Perangkat pembelajaran dikembangkan berdasarkan 3 aspek utama yaitu potensi lokal, literasi lingkungan, dan sikap konservasi. Potensi lokal yang diambil bersumber dari potensi lokal yang ada di Kabupaten Kubu Raya meliputi bidang SDA dan SDM. Studi pendahuluan terkait potensi lokal dilakukan dengan cara studi pustaka dan survey lapangan di Desa Sui Kakap, Desa Rasau Jaya, Desa Padang Tikar, dan Desa Kapur. Literasi lingkungan yang digunakan bersumber dari hasil rumusan OECD (2007) dan NAAEE (2000) bahwa ada tiga komponen literasi lingkungan yaitu kompetensi lingkungan, pengetahuan lingkungan, dan sikap terhadap lingkungan. Sikap konservasi dalam perangkat bahan ajar yang dikembangkan meliputi praktek konservasi, program konservasi, dan pelopor konservasi.

Tahap Perencanaan (define) bertujuan untuk menetapkan dan mendefinisikan syaratsyarat pembelajaran biologi di SMA dalam hal ini terkait analisis karakteristik siswa, analisis materi biologi, dan perumusan tujuan dalam perangkat pembelajaran yang dikembangkan. Analisis karakteristik siswa menggunakan siswa kelas $\mathrm{X}$ SMAN 2 Sui Raya dengan cara observasi dan wawancara. Analisis materi biologi dilakukan dengan wawancara langsung kepada ketua Musyawarah Guru Mata Pelajaran (MGMP) biologi Kabupaten Kubu Raya, dan perumusan tujuan dilakukan dengan metode diskusi bersama guru biologi di SMAN 2 Sui Raya.

Tahap perancangan (design) bertujuan untuk merancang pengembangan perangkat pembelajaran biologi. Penyusunan pedoman validasi untuk menghasilkan pengembangan perangkat pembelajaran biologi berbasis potensi lokal yang valid berdasarkan aspek bahasa, grafika dan isi. Pembuatan angket respon peserta didik untuk menghasilkan perangkat pembelajaran biologi yang praktis berdasarkan aspek kemudahan dan keterbantuan dalam proses pembelajaran. Penyusunan perangkat pengukuran hasil belajar dimulai dengan penyusunan kisi-kisi soal. Kisi-kisi disusun dengan berdasarkan tujuan pembelajaran kemudian diikuti dengan pembuatan soal.

Tahap pengembangan (develop) adalah tahap untuk menghasilkan produk pengembangan yang dilakukan melalui dua langkah, yakni: (1) penilaian ahli (expert appraisal) yang diikuti dengan revisi, (2) uji coba pengembangan (developmental testing). Tujuan tahap pengembangan ini adalah untuk menghasilkan bentuk akhir perangkat pembelajaran biologi setelah melalui revisi berdasarkan masukan para validator dan data hasil uji coba. Penilaian para validator terhadap pengembangan perangkat pembelajaran biologi mencakup: aspek penyajian 
materi/isi, gambar dan bahasa, serta komponen grafika. Validasi akan dilakukan oleh 1 dosen Program Studi Pendidikan Biologi Fakultas Keguruan dan Ilmu Pendidikan Universitas Muhammadiyah Pontianak dan 2 guru mata pelajaran Biologi SMAN 1 Batu Ampar dan SMAN 1 Sui Kakap. Uji coba menggunakan peserta didik yang berasal dari 1 kelas di kelas $\mathrm{X}$ SMAN 2 Sui Raya. Untuk mengukur tingkat kevalidan produk pengembangan perangkat pembelajaran biologi, digunakan teknik analisis sebagai berikut :

$$
\mathrm{P}=\frac{\sum_{i=1}^{4} x_{i}}{\sum_{j=1}^{4} x_{j}} \times 100 \%
$$

Keterangan :

$\mathrm{P} \quad=$ Persentase pilihan

$\Sigma \mathrm{x}_{\mathrm{i}}=$ Jumlah skor jawaban penilaian

oleh ahli

$\Sigma \mathrm{x}_{\mathrm{j}}=$ Jumlah skor jawaban tertinggi

Sedangkan sebagai dasar pengambilan keputusan untuk merevisi perangkat pembelajaran biologi digunakan kriteria penilaian:

Tabel 1 Kriteria Kevalidan Perangkat Pembelajaran Biologi

\begin{tabular}{lll}
\hline $\begin{array}{c}\text { Persentase } \\
(\boldsymbol{\%})\end{array}$ & $\begin{array}{l}\text { Kriteria } \\
\text { Kevalidan }\end{array}$ & Keterangan \\
\hline $80-100$ & Sangat valid & Tidak revisi \\
$66-79$ & Valid & Tidak revisi \\
$56-65$ & Cukup valid & Tidak revisi \\
$40-55$ & Kurang valid & Revisi \\
$30-39$ & Tidak valid & Revisi \\
\hline
\end{tabular}

Penyempurnaan produk perangkat pembelajaran biologi dilakukan berdasarkan hasil uji coba pengembangan. Penyempurnaan produk pengembangan perangkat pembelajaran biologi dilakukan agar perangkat pembelajaran biologi digunakan dalam kegiatan pembelajaran.

\section{HASIL DAN PEMBAHASAN}

1. Define

Tahap ini bertujuan untuk menetapkan dan mendefinisikan syarat-syarat pembelajaran. Pada tahap define terdapat empat kegiatan yang dilakukan, yaitu analisis awal akhir, analisis peserta didik, analisis materi dan perumusan tujuan.

Tabel 2. Hasil Tahap Define

\begin{tabular}{|c|c|}
\hline Tahap & Hasil \\
\hline $\begin{array}{l}\text { Analisis awal } \\
\text { akhir }\end{array}$ & $\begin{array}{l}\text { a. Perangkat } \\
\text { pembelajaran yang } \\
\text { dikembangkan } \\
\text { meliputi Rencana } \\
\text { Pelaksanaan } \\
\text { Pembelajaran (RPP), } \\
\text { Bahan Ajar, dan } \\
\text { Lembar Kegiatan } \\
\text { Siswa (LKS). } \\
\text { b. Potensi lokal yang } \\
\text { diambil bersumber } \\
\text { dari potensi lokal } \\
\text { yang ada } \\
\text { Kabupaten Kubu } \\
\text { Raya meliputi bidang } \\
\text { SDA dan SDM. } \\
\text { Literasi lingkungan } \\
\text { yang digunakan } \\
\text { bersumber dari hasil } \\
\text { rumusan OECD } \\
\text { (2007) dan NAAEE } \\
\text { (2000) bahwa ada } \\
\text { tiga komponen } \\
\text { literasi lingkungan } \\
\text { yaitu kompetensi } \\
\text { lingkungan, } \\
\text { pengetahuan }\end{array}$ \\
\hline
\end{tabular}




\begin{tabular}{|c|c|}
\hline & $\begin{array}{l}\text { lingkungan, dan } \\
\text { sikap terhadap } \\
\text { lingkungan. } \\
\text { d. Sikap konservasi } \\
\text { dalam perangkat } \\
\text { bahan ajar yang } \\
\text { dikembangkan } \\
\text { meliputi praktek } \\
\text { konservasi, program } \\
\text { konservasi, dan } \\
\text { pelopor konservasi.. }\end{array}$ \\
\hline $\begin{array}{l}\text { Analisis } \\
\text { peserta didik }\end{array}$ & $\begin{array}{l}\text { Berdasarkan hasil } \\
\text { wawancara, peserta didik } \\
\text { belum mengetahui cara } \\
\text { memaksimalkan dan } \\
\text { menjaga potensi lokal di } \\
\text { daerahnya. Peserta didik } \\
\text { juga belum memiliki } \\
\text { literasi lingkungan dan } \\
\text { sikap konservasi jika } \\
\text { dilihat dari kondisi } \\
\text { ruangan kelas yang kotor } \\
\text { dan perilaku membuang } \\
\text { sampah sembarangan. }\end{array}$ \\
\hline $\begin{array}{l}\text { Analisis } \\
\text { materi }\end{array}$ & $\begin{array}{l}\text { Salah satu materi } \\
\text { yang } \\
\text { dikembangkan dalam } \\
\text { perangkat pembelajaran } \\
\text { adalah Ekosistem dan } \\
\text { Keanekaragaman Hayati } \\
\text { untuk materi di kelas X } \\
\text { SMA. }\end{array}$ \\
\hline $\begin{array}{l}\text { Perumusan } \\
\text { tujuan }\end{array}$ & \begin{tabular}{lr}
\multicolumn{2}{c}{ Kompetensi inti } \\
Menganalisis & hubungan \\
antara & komponen \\
ekosistem dan peranan \\
manusia & dalam \\
keseimbangan ekosistem, \\
sedangkan kompetensi \\
dasar Mendeskripsikan \\
peran & komponen \\
ekosistem & dan \\
pemanfaatan & komponen \\
ekosistem & bagi \\
kehidupan. &
\end{tabular} \\
\hline
\end{tabular}

\section{Design}

Dalam tahapan ini adalah perancangan perangkat pembelajaran. Pada tahap ini terdiri dari penyusunan instrumen dan pemilihan format perangkat pembelajaran.

Tabel 3. Hasil Tahap Design

\begin{tabular}{ll}
\hline Tahap & \multicolumn{2}{c}{ Hasil } \\
\hline & Tahap ini meliputi \\
penyusunan : & 1. Instrumen \\
& kevalidan berupa \\
& lembar penilaian \\
& perangkat \\
& pembelajaran. \\
& Aspek penilaian \\
& merupakan hasil \\
& modifikasi dari \\
& komponen penilaian \\
& aspek kelayakan \\
& kegrafikan dan \\
& kelayakan bahan \\
Penyusunan & ajar oleh Badan \\
instrumen & Standar Nasional \\
& Pendidikan (BSNP).
\end{tabular}

\section{Instrumen}

kepraktisan berupa lembar angket respon peserta didik. Angket respon peserta didik disusun berdasarkan Kemudahan

Pemahaman,

Kemandirian

belajar, Keaktifan dalam belajar, Minat, Penyajian 


dan Penggunaan
perangkat
pembelajaran.
3. Instrumen
keefektifan berupa
tes yang dikerjakan
oleh peserta didik
diakhir
pembelajaran.
Instrumen
keefektifan ini
dibuat berdasarkan
standar kompetensi
dan kompetensi
dasar.
Tahap ini meliputi
penyusunan format
perangkat
pembelajaran. Tahap
ini meliputi halaman
sampul,
pengantar, daftar isi,
pendahuluan,
perencanaan
pembelajaran, bahan
ajar,
praktikum lapangan,
daftar pustaka serta
gambar potensi lokal

3. Develop

Tahap Develop menghasilkan perangkat pembelajaran biologi yang layak berdasarkan masukan ahli (validator).

a. Validasi ahli Perangkat Pembelajaran Biologi SMA
Validasi ahli merupakan kegiatan yang dilakukan untuk mereview dan melihat aspek kevalidan perangkat pembelajaran biologi SMA yang dikembangkan. Kevalidan diperoleh berdasarkan hasil penilaian validator. Validator tersebut berjumlah 3 orang. Adapun hasil penilaian validator adalah sebagai berikut :

1) Format tulisan dan tata cara penulisan mengikuti kaidah KBBI.

2) Desain cover tidak mewakili potensi lokal Kalimantan Barat

3) Konservasi dan literasi lingkungan lebih ditonjolkan dalam isi penuntun praktikum lapangan yang ada di perangkat pembelajaran

4) RPP mengikuti kaidah dan format kurikulum 2013

5) Lampiran potensi lokal yang ada di Kalimantan Barat dibedakan sesuai bidang (SDA, SDM, Seni dan Budaya, Pariwisata, Kuliner, dll)

6) Kedalaman materi dan konsep harus jelas sehingga pesan yang hendak disampaikan dapat diterima dengan baik dan jelas.

7) Perbaiki tata letak gambar dan highlight konsep yang penting agar tidak monoton dan menimbulkan rasa bosan pengguna 
8) Perbaiki beberapa gambar yang kurang jelas

b. Kevalidan Perangkat Pembelajaran Biologi

Hasil validasi aspek kevalidan menunjukan aspek bahasa $85 \%$, aspek materi $87 \%$ dan aspek kegrafikan $80 \%$. Semua aspek yang diamati termasuk dalam kriteria sangat baik (Tabel 4)

Tabel 4. Penilaian ahli terhadap perangkat pembelajaran

\begin{tabular}{lcc}
\hline \multicolumn{1}{c}{ Aspek } & $\begin{array}{c}\% \\
\text { Kevalidan }\end{array}$ & Kriteria \\
\hline Bahasa & 85 & Valid \\
Materi & 87 & Valid \\
Kegrafikan & 80 & Valid \\
\hline
\end{tabular}

c. Kepraktisan Perangkat Pembelajaran

Berdasarkan respon peserta didik yang mengikuti proses pembelajaran menggunakan perangkat pembelajaran biologi yang telah dikembangkan. Pengamatan respon peserta didik ketika uji coba skala kecil dan uji coba skala besar. Respon peserta didik pada uji coba skala kecil berjumlah 10 peserta didik kelas X A berdasarkan kemampuan peserta didik yaitu tingkat tinggi, sedang dan rendah. Respon peserta didik pada uji coba skala besar berjumlah 30 peserta didik kelas X A berdasarkan kemampuan peserta didik yaitu tingkat tinggi, sedang dan rendah. Adapun hasil respon peserta didik sebagai berikut:

Hasil uji coba skala kecil menunjukkan aspek kemudahan pemahaman sebesar 85.73, kemandirian belajar 85,58, keaktifan dalam belajar 82,41 , minat 80,55 , penyajian 83,50 , penggunaan sebesar 84,20 . Semua aspek yang diamati termasuk dalam kriteria sangat baik (Tabel 5)

Tabel 5. Respon Peserta Didik Uji Coba Kecil

\begin{tabular}{|c|c|c|}
\hline Aspek & NRS & Kriteria \\
\hline Kemudahan & \multirow{3}{*}{85.73} & Sangat \\
\hline Pemahaman & & Baik \\
\hline Kemandirian & & Sangat \\
\hline Belajar & \multirow[t]{2}{*}{85.58} & Baik \\
\hline Keaktifan & & Sangat \\
\hline Dalam Belajar & \multirow[t]{2}{*}{82.41} & Baik \\
\hline Minat & & Sangat \\
\hline & \multirow[t]{2}{*}{80.55} & Baik \\
\hline Penyajian & & Sangat \\
\hline & \multirow[t]{2}{*}{83.50} & Baik \\
\hline Penggunaan & & Sangat \\
\hline & 84.20 & Baik \\
\hline
\end{tabular}

Hasil uji coba skala besar menunjukkan aspek kemudahan pemahaman sebesar 90.41, kemandirian belajar 85,83, keaktifan dalam belajar 82,92, minat sebesar 87,78, penyajian sebesar 84,33, penggunaan sebesar 86,87. Semua aspek yang diamati termasuk dalam kriteria sangat baik (Tabel 6)

Tabel 6 Respon Peserta Didik Uji Coba Skala Besar

Aspek NRS Kriteria




\begin{tabular}{lcc}
\hline $\begin{array}{l}\text { Kemudahan } \\
\text { Pemahaman }\end{array}$ & 89,16 & $\begin{array}{c}\text { Sangat } \\
\text { Kemandirian } \\
\text { Sangat } \\
\text { Belajar }\end{array}$ \\
$\begin{array}{l}\text { Keaktifan } \\
\text { Dalam Belajar } \\
\text { Minat }\end{array}$ & 85,83 & $\begin{array}{c}\text { Baik } \\
\text { Sangat } \\
\text { Baik }\end{array}$ \\
Penyajian & 87,78 & $\begin{array}{c}\text { Sangat } \\
\text { Baik } \\
\text { Sangat } \\
\text { Baik } \\
\text { Pangat } \\
\text { Baik }\end{array}$ \\
\hline
\end{tabular}

d. Keefektifan Perangkat Pembelajaran Keefektifan perangkat pembelajaran dilakukan dengan cara pemberian tes tertulis. Nilai klasikal hasil belajar dapat dilihat pada tabel 4.8. Hasil uji coba skala kecil menunjukan dari 10 peserta didik yang yang mengikuti tes terdapat 7 orang tuntas dan memiliki persentase ketuntasan klasikal7\%. Hasil uji coba skala besar menunjukan dari 30 peserta didik yang yang mengikuti tes terdapat 26 orang tuntas dan memiliki rata-rata nilai klasikal $86,87 \%$ (Tabel 7)

Tabel 7 Nilai klasikal hasil belajar peserta didik pada uji coba skala kecil dan skala besar

\begin{tabular}{cccc}
\hline $\begin{array}{c}\text { Uji } \\
\text { coba }\end{array}$ & $\begin{array}{c}\text { Pumlah } \\
\text { Peserta } \\
\text { didik }\end{array}$ & Total & $\begin{array}{c}\text { Ketuntasan } \\
\text { Klasikal }\end{array}$ \\
\hline $\begin{array}{c}\text { Skala } \\
\text { Kecil }\end{array}$ & 10 & 7 & $70 \%$ \\
\hline $\begin{array}{c}\text { Skala } \\
\text { Besar }\end{array}$ & 30 & 26 & $86,87 \%$ \\
\hline
\end{tabular}

Keterangan :

$\begin{array}{ll}\text { Nilai maks } & =100 \\ \mathrm{KKM} & =70\end{array}$

$$
\text { Ketuntasan Klasikal }=70
$$

\section{Pembahasan}

Permasalahan yang terjadi di lapangan dalam hal ini SMA di Kabupaten Kubu Raya adalah dalam proses pembelajaran memerlukan tambahan referensi pelajaran untuk menambah pengetahuan siswa terkait potensi lokal yang dapat menimbulkan literasi lingkungan sehingga siswa dapat menumbuhkembangkan sikap konservasi yang ada pada dirinya. Menurut Ni'mah (2016) referensi baru atau media baru merupakan salah satu faktor yang turut menentukan keberhasilan pembelajaran karena dapat membantu siswa dan guru menyampaikan pelajaran. Semakin banyak referensi yang digunakan siswa dan guru dalam proses pembelajaran, maka proses belajar biologi menjadi lebih baik.

Pada tahap analisis peserta didik didapatkan bahwa peserta didik ingin belajar diluar kelas dan mengeksploasi lingkungan sekolahnya. Untuk itu, perlu dikembangkan suatu proses pembelajaran yang mendukung karakteristik peserta didik tersebut. Menurut Handayani dkk. (2013) umumnya peserta didik lebih senang belajar dengan cara memberikan kesempatan kepada mereka untuk bekerja mandiri dari pada dijelaskan secara detail seperti berceramah di depan kelas. Untuk mencocokkan keinginan peserta didik dan perangkat pembelajaran yang dikembangkan maka dipilihlah materi ekosistem. Menurut Ibrohim (2015) Melalui pembelajaran lingkungan diharapkan juga dapat meningkatkan kebermaknaan pembelajaran sains dan menghargai lingkungan sekitar. Materi ekosistem dipilih dengan bahasan komponen-komponen ekosistem dan pola interaksi dalam ekosistem. Peserta didik akan melakukan kegiatan sesuai rancangan perangkat 
pembelajaran berbasis potensi lokal, literasi lngkungan, dan sikap konservasi. Menurut Lamasai, dkk (2014) Manfaat yang diperoleh dalam menggunakan lingkungan sebagai sumber adalah peserta didik dapat melihat secara langsung bendabenda yang berkaitan dengan mata pelajaran di sekolahnya, peserta didik dapat membuktikan dan menerapkan teori atau konsep yang pernah didapat ke dalam kehidupan sehari-hari. Dengan cara mengamati secara langsung peserta didik akan memiliki kesempatan untuk menghubungkan antara teori dan kenyataan.

Model pembelajaran Biologi mampu mendorong siswa membangun konsep mereka sendiri, bersifat kontekstual, melibatkan aspek-aspek kehidupan sehari-hari siswa, dan memanfaatkan alam sekitar, lingkungan dan potensi lokal di mana siswa berada, sehingga dapat meningkatkan kemampuan literasi sains siswa (Putri, 2014). Pendapat Capra dalam Keraf (2014) memaparkan bahwa literasi ekologi sebagai suatu keadaan di mana orang telah memahami prinsip-prinsip ekologi dan hidup sesuai prinsip-prinsip ekologi itu dalam menata dan membangun kehidupan bersama umat manusia di bumi ini dalam dan untuk mewujudkan masyarakat berkelanjutan. Oleh sebab itu, perlu adanya jembatan sebagai penyampai agar siswa dapat memahami arti literasi ekologi. Melalui pendidikan yang diintegrasikan dalam pembelajaran biologi maka siswa akan mengenal, memahami, dan menerapkan literasi ekologi sebagai dasar segala tindakannya terhadap alam.

Berdasarkan hasil penerapan perangkat pembelajaran biologi di sekolah diperoleh hasil efektif. Hal ini dikarenakan peserta didik langsung belajar di alam dan dengan sumber potensi lokal yang ada di daerahnya sendiri. Menurut Sitanggang dan Yulistiana (2015) belajar ekosistem di alam sekitar dapat meningkatkan hasil belajar biologi peserta didik pada materi ekosistem. Keunggulan lokal dapat dijadikan sumber belajar biologi. Menurut Mumpuni (2013:3) menjelaskan bahwa potensi lokal dapat dujadikan sumber belajar biologi. Menurut Situmorang (2016) Potensi lokal di lingkungan sekolah sangat mendukung pembelajaran biologi khususnya materi ekosistem. Melalui potensi lokal tersebut peserta didik dapat diajak untuk melakukan pengamatan ekosistem di lingkungan sekolah dan luar sekolah, mengidentifikasi komponen ekosistem sehingga dapat meningkatkan hasil belajar siswa. Konsep ekosistem menarik untuk diteliti karena sangat berkaitan dengan kehidupan nyata. Melalui pembelajaran di lapangan peserta didik dapat membangun pengetahuannya tentang potensi lokal yang dimiliki daerahnya. Menurut Muthmainnah dkk (2016) penggunaan media berbasis potensi lokal terbukti dapat meningkatkan pemahaman konsep dan sikap peduli lingkungan peserta didik. Potensi lokal suatu daerah perlu dikembangkan karena merupakan ciri khas yang dimiliki oleh daerah tersebut.

Di sinilah letak literasi ekologi menjadi mendesak, untuk diterapkan dalam pembelajaran biologi. Proses pembelajaran biologi untuk meningkatkan literasi ekologi membutuhkan pendekatan, media dan sumber belajar yang mengundang siswa untuk aktif terlibat langsung, proses pembelajaran harus memberikan kesempatan kepada seluruh siswa agar siswa dapat mengembangkan potensi. Proses pembelajaran yang akan mengarahkan siswa menjadi aktif dengan melibatkan seluruh alat indera, baik fisik maupun intelektual dengan pengalaman siswa itu sendiri 
(Rahayu 2016). Hal ini sesuai dengan hasil penelitian Sujarwo (2015) bahwa dipilihnya panduan model pendidikan sadar lingkungan bermuatan potensi lokal mengenai pemanfaatan lahan pekarangan dengan tanaman sayuran atas dasar pertimbangan: (1) memenuhi kebutuhan belajar program model pendidikan sadar lingkungan melalui pendidikan kecakapan hidup bermuatan potensi lokal dengan memanfaatkan lahan pekarangan melalui tanaman sayuran pada peserta didik; (2) dapat digunakan fasilitator sebagai sarana strategi dalam pendidikan sadar lingkungan melalui pemanfaatan lahan pekarangan dengan tanaman sayuran berbagai model; (3) dapat digunakan peserta didik belajar secara mandiri.

Perangkat pembelajaran biologi yang dikembangkan juga efektif untuk memberikan pendidikan konservasi dalam diri siswa. Hal ini sesuai dengan penelitian Leksono (2013) bahwa terdapat empat jenis karakter konservasi yang dapat dikembangkan selama proses pendidikan, yaitu (1) pendidikan karakter berbasis nilai budaya, yang merupakan kebenaran wahyu Tuhan (konservasi moral); (2) pendidikan karakter berbasis budaya, antara lain yang berupa budi pekerti, pancasila, apresasi sastra, keteladanan tokoh-tokoh sejarah dan para pemimpin bangsa (konservasi budaya); pendidikan karakter berbasis lingkungan (konservasi lingkungan),dan (4) pendidikan karakter berbasis potensi diri, yaitu sikap pribadi, hasil proses kesadaran pemberdayaan potensi diri yang diarahkan untuk meningkatkan kualitas pendidikan (konservasi humanis). Pernyataan ini juga didukung oleh Sukardi (2015) bahwa Pembelajaran di luar kelas didasarkan pada konsep bahwa potensi lokal merupakan sumber belajar berbasis lingkungan, sehingga keberadaan lingkungan menjadi sumber daya yang dapat dimanfatkan oleh siswa. Dengan demikian, pembelajaran di luar kelas memberikan peluang kepada siswa untuk memperoleh pengetahuan dan keterampilan melalui pelibatan dalam dunia nyata. Pembelajaran di luar kelas juga dapat menghindari kejenuhan, kebosanan, dan persepsi belajar hanya di dalam kelas.

\section{KESIMPULAN DAN SARAN}

Berdasarkan hasil penelitian yang telah dilakukan dapat disimpulkan sebagai berikut: 1) Perangkat pembelajaran biologi memenuhi aspek kevalidan pada aspek bahasa, aspek materi dan aspek kegrafikan. 2) Perangkat pembelajaran biologi memenuhi aspek kepraktisan dengan respon peserta didik kriteria positif. 3) Perangkat pembelajaran biologi yang dikembangkan memenuhi aspek keefektifan yang tinggi.

\section{UCAPAN TERIMAKASIH}

Terima kasih kepada Kemristekdikti yang telah memberikan bantuan dalam penelitian dan LPPM UM Pontianak yang telah memberikan dukungan moril sehingga penelitian ini dapat terlaksana dengan baik.

\section{DAFTAR PUSTAKA}

Achyani. 2010. Pengembangan Model Penulisan Buku Pelajaran Biologi SMA Berwawasan Ekologi dan Berbasis Realitas Lokal. (Disertasi). Program Doktor Sekolah Pascasarjana, Universitas Pendidikan Indonesia, Bandung.

Almutahar AM, Sutjipto DO, Sukandar. 2013. Analisis Strategi Pengelolaan Pelabuhan Perikanan Pantai Sungai Rengas Kabupaten Kubu Raya Kalimantan Barat. PSPK Student Journal 1(1): 1-10. 
Handayani, Putri Lena dkk. 2013. Pengembangan Buku Penuntun Praktikum Ipa Berbasis Inkuiri Terbimbing Untuk SMP Kelas VII Semester II. UNP.

Ibrohim. 2015. Pengembangan Pembelajaran Ipa/Biologi Berbasis Discovery/Inquiry dan Potensi Lokal Untuk Meningkatkan Keterampilan Dan Sikap Ilmiah Serta Menumbuhkan Jiwa Kewirausahaan. Prosiding Semnas Sains \& Enterpreneurship II. ISBN:978-602-99975$1-4$

Ihat H. 2006. Pengelolaan Pembelajaran Berbasis Potensi Lokal di PKBM. Mimbar Pendidikan 1(25): 39-45.

Keraf AS. 2014. Filsafat Lingkungan Hidup: Alam Sebagai Sebuah Sistem Kehidupan. Yogyakarta: PT. Kanisius.

Khusniati. 2014. Model Pembelajaran Sains Berbasis Kearifan Lokal dalam Menumbuhkan Karakter Konservasi. Indonesian Journal of Conservation, 3 (1): 67-74.

Lamasai, Muzria S dkk. 2014. Pemanfaatan Lingkungan Alam Sekitar Sebagai Sumber Belajar Dalam Meningkatkan Hasil Belajar IPA Siswa Kelas III SDN 10 Gadung. Jurnal Kreatif Tadulako.Vol. 5, No.3. ISSN 2354-614X

Leksono, S.M. et al. 2013. Kemampuan Profesional Guru Biologi dalam Memahami dan Merancang Model Pembelajaran Konservasi Biodiversitas di SMA. Jurnal Cakrawala Pendidikan, 32 (3): 408-419.

Marlina R. 2013. Pemanfaatan Lingkungan Lokal dalam Kegiatan Laboratorium Berbasis Inkuiri Terhadap Kerja Ilmiah Mahasiswa Calon Guru Biologi. (Tesis). Program Magister Sekolah Pascasarjana, Universitas Pendidikan Indonesia, Bandung.

Mumpuni, Kistantia Elok dkk. 2013. Potensi Tumbuhan Lokal Sebagai Sumber Belajar Biologi. Seminar Nasional XI Pendidikan Biologi FKIP UNS.

Muthmainah dkk. 2016. Pengaruh Penggunaan Modul Berbasis Potensi Lokal pada Topik Ekosistem terhadap Pemahaman Konsep dan Sikap Peduli Lingkungan Siswa Kelas $X$. Proceeding Biology Education Conference. Vol.13 No. 2. ISSN: 25285742.
Ni'mah, Durrotun. 2016. Pengembangan Modul Gambar Proses Untuk Pembelajaran Fisika di SMA. Pros. Semnas Pend. IPA Pascasarjana. Vol. 1. ISBN. 978-602-928621-27.

Putri A, Suciati, Ramli M . 2014. Pengaruh Model Problem Based Learning Berbasis Potensi Lokal pada Pembelajaran Biologi terhadap Kemampuan Literasi Sains Siswa Kelas X SMA Negeri 1 Cepogo. Jurnal BIOPEDAGOGI, 3 (2): 81-94.

Santoso AM. 2010. Konsep Diri melalui Pendidikan Berbasis Keunggulan Lokal sebagai Model Pendidikan Berkarakter dan Berbudaya Bangsa di Era Global. Proceedings of The 4th International Conference on Teacher Education; Join Conference UPI \& UPSI. Bandung: UPI.

Sitanggang, Netty Demak H dan Yulistiana. 2015. Peningkatan Hasil Belajar Ekosistem Melalui Penggunaan Laboratorium Alam. Jurnal Formatif. Vol.5.No2. ISSN: 2088$351 X$.

Situmorang, Risya Pramana. 2016. Analisis Potensi Lokal Untuk Mengembangkan Bahan Ajar Biologi di SMA Negeri 2 Wonosari. Jurnal Pendidikan Sains. Vol. 4, No.1.

Sukardi. 2016. Desain Model Prakarya dan Kewirausahaan Berbasis Ekonomi Kreatif Berdimensi Industri Keunggulan Lokal. Jurnal Cakrawala Pendidikan. Th XXXV, No.1.

Sujarwo, dkk. 2015. Model Pendidikan Sadar Lingkungan Masyarakat Korban Erupsi Merapi Berbasis Potensi Lokal. Jurnal Cakrawala Pendidikan. TH.XXXIV, No. 1.

Surata SP, Vipriyanti SU, Falk I. 2010. Social Network Analysis For Assessing Social Capital In Biosecurity Ecoliteracy. Jurnal Ilmu Pendidikan, 17 (3): 238-244.

Valentine DA. 2015. Peningkatan Ecoliteracy Siswa dalam Pemanfaatan Kebun Karet Sebagai Sumber Pembelajaran IPS. Jurnal Pendidikan Ilmu Sosial, 24 (2): 223-231.

Victorino D. 2004. Global Responsibility and Local Knowledge System. Conference held in Egypt.

Yunisfu. 2013. Pembelajaran Kimia Unsur Menggunakan Konteks Keunggulan Lokal Tambang Timah di Pulau Bangka dan Pengaruhnya Pada Literasi Sains Siswa SMA Kelas XII. [Tesis]. Universitas Pendidikan Indonesia. Bandung 